\title{
Impression cytology and in vivo confocal microscopy in corneas with total limbal stem cell deficiency
}

\author{
Citologia de impressão e microscopia confocal in vivo em córneas com deficiência total \\ das células-tronco do limbo
}

Aline lütz de Araújo ${ }^{1}$, José Reinaldo da Silva Ricardo ${ }^{1}$, Vivian Naomi Sakal ${ }^{1}$, Jeison Nadai de Barros ${ }^{1}$, José Álvaro Pereira Gomes ${ }^{1}$

\begin{abstract}
Purposes: To describe corneal changes seen on in vivo confocal microscopy in patients with total limbal stem cell deficiency and to correlate them with cytological findings.

Methods: A prospective case series including 13 eyes (8 patients) with total limbal deficiency was carried out. Stem cell deficiency was diagnosed clinically and by corneal impression cytology. Confocal images of the central cornea were taken with the Heidelberg Retina Tomograph II, Rostock Corneal Module (Heidelberg Engineering, Heidelberg, Germany).

Results: Impression cytology of the cornea revealed conjunctival epithelial cells and goblet cells in all cases. In vivo confocal microscopy showed disruption of normal layers of the corneal epithelium in all eyes. Confocal images showed cells with characteristics of conjunctival epithelium at the cornea in $76.9 \%$ of the total. These findings on confocal microscopy were compatible to limbal stem cell deficiency. Additionally, goblet cells, squamous metaplasia, inflammatory cells and dendritic cells were observed. The sub-basal nerve plexus was not identified in any of the corneas. Corneal neovessels were observed at the epithelium and stroma. All cases showed diffuse hyper-reflective images of the stroma corresponding to opacity of the tissue.

Conclusions: Limbal stem cell deficiency had been confirmed by impression cytology in all cases, and $76.9 \%$ of the cases could also be diagnosed by in vivo confocal microscopy through the conjunctival epithelial cell visualization on the corneal surface. Frequent confocal microscopy findings were abnormal cells at the cornea (conjunctival epithelial, goblet and inflammatory cells), corneal neovessels and diffuse hyper-reflection of the stroma.
\end{abstract}

Keywords: Cornea/cytology;Corneal diseases; Conjunctiva/cytology; Limbus corneae; Stem cells; Microscopy, Confocal

\section{RESUMO}

Objetivos: Descrever as alterações corneais observadas na microscopia confocal in vivo e relacioná-las aos achados da citologia de impressão em pacientes com deficiência total das células-tronco do limbo.

Métodos: Série de casos prospectiva incluindo 13 olhos (8 pacientes) com deficiência total das células-tronco do limbo. Adeficiência límbica foi diagnosticada clinicamente e mediante citologia de impressão da córnea. Imagens confocais da córnea central foram obtidas com o Heidelberg Retina Tomograph II, Rostock Corneal Module (Heidelberg Engineering, Heidelberg, Alemanha).

Resultados: A citologia de impressão da córnea demonstrou células epiteliais da conjuntiva e células caliciformes em todos os casos. A microscopia confocal da área central da córnea mostrou alteração da estrutura normal das camadas do epitélio corneal em todos os casos. As imagens confocais da córnea mostraram a presença de células com características do epitélio conjuntival em 76,9\%. Esses achados no exame confocal são compatíveis com deficiência das células-tronco do limbo. Adicionalmente, células caliciformes, metaplasia escamosa, células inflamatórias e dendríticas foram observadas. 0 plexo nervoso sub-basal não foi identificado em nenhum dos casos. Neovasos corneais foramobservados no epitélio eno estroma. Em todosos casos haviaimagens difusamente hiperreflectivas no estroma, correspondendo à opacidade do tecido.

Conclusões: A deficiência das células-tronco do limbo, previamente confirmada por citologia de impressão, pôde ser demonstrada pela microscopia confocal in vivo em $76,9 \%$ dos casos através da visualização de células epiteliais da conjuntiva na córnea. Achados frequentes na microscopia confocal foram células anormais na córnea (células conjuntivais, caliciformes e inflamatórias), neovasos corneais e hiperreflexão difusa do estroma.

Descritores: Córnea/citologia;Doenças da córnea; Túnica conjuntiva/citologia; Limbo da córnea; Células-Tronco; Microscopia confocal

\section{INTRODUCTION}

Corneoscleral limbus is the site of corneal epithelial stem cells ${ }^{(1-4)}$. Limbal stem cell deficiency (LSCD) is a clinical condition that occurs in a variety of ocular diseases, including ocular chemical injuries, Stevens Johnson syndrome and ocular cicatricial pemphigoid(4,5). Typical LSCD symptoms are decreased vision, photophobia, tearing, burning and recurrent pain episodes ${ }^{(1,6)}$. The clinical picture is a conjunctivalized corneal surface with neovessels and recurrent or persistent epithelial defects ${ }^{(1,4,6)}$

Tests for LSCD should demonstrate the presence and the extension of the deficiency. Other tests routinely performed target associated conditions like dry eye and neuroanatomical changes of the corneal surface. These tests include biomicroscopy, ocular surface staining with fluorescein, Schirmer tests, tearfilm breakup time, and corneal esthesiometry ${ }^{(7)}$. Impression cytology is used to demonstrate goblet cells on the corneal surface and confirm the diagnosis of LSCD ${ }^{(5,8,9)}$. However, it is important to consider the possibility of a false-negative diagnosis of LSCD when the presence of goblet cells is the only criterion considered, since a lack of these cells can happen on the sample by chance ${ }^{(6,10)}$. More recently, in vivo confocal microscopy (IVCM) made possible to evaluate in vivo all corneal layers, from the epithelium to endothelium ${ }^{(11-14)}$ and its use to diagnose LSCD has already been attempted ${ }^{(15,16)}$. IVCM shows corneal structures at different depths through the light reflected from the tissue. As
Funding: No specific financial support was available for this study. Disclosure of potential conflicts of interest: A.L.de Araújo, None; J.R.S.Ricardo, None; V.N.Sakai, None; J.N.de Barros, None; J.A.P.Gomes, None.

Corresponding address: Aline Lütz de Araújo. Rua Professor Cristiano Fischer, 34 - Porto Alegre (RS) - 90410-000 - Brazil -E-mail: alinelutz.a@gmail.com

Ethical approval: Project number 0287/10 approved by the institutional Ethics Committee in Research. 
a non-invasive, fast exam, IVCM can be repeated as many times as needed to follow up a corneal condition and its response to treatment ${ }^{(12)}$. Histopathological examinations are usually not repeated for being invasive, and are associated to ex vivo artifacts. IVCM is more commonly used for infective keratitis diagnosis, particularly Acanthamoeba or fungal infections, and for endothelial examination during corneal edema ${ }^{(12,13)}$. In addition to providing qualitative information, IVCM also allows for quantitative analysis by showing the density of corneal cells or nerves and determining the amount of corneal light scatter and the depth of visible structures, such as surgically created interfaces ${ }^{(12,13,17)}$. IVCM has been safely used in unstable ocular surface such as corneas with recurrent epithelial erosions ${ }^{(18,19)}$ or immediately after phototherapeutic keratotomy ${ }^{(20)}$.

The aim of this study is to describe corneal changes seen on IVCM in patients with total LSCD and to correlate them with impression cytology findings.

\section{METHODS}

We conducted a cross-sectional study with patients with total LSCD from the Cornea and External Disease Section of the Department of Ophthalmology, Universidade Federal de São Paulo, in Brazil. Ethical approval was obtained from the Institutional Medical Ethics Committee and National Ethics Committee in Research and followed the Tenets of the Declaration of Helsinki. Informed consent was obtained from the subjects after explanation of the nature and possible consequences of the study. The inclusion criteria were diagnosis of total LSCD based on the presence of conjunctival epithelial ingrowth onto the cornea in 4 quadrants (clinical signs observed are loss of corneal epithelial transparency, superficial corneal neovascularization, and epithelial irregularity or recurrent epithelial breakdown) $)^{(1,15)}$ and on impression cytology (presence of goblet cells in 4 quadrants of the corneal surface).

For impression cytology, we used cellulose acetate filters with a pore size of 0.45 micron (Millipore Corporation, Bedford, USA). Filters were cut in triangle shapes for orientation purposes and then applied to the conjunctiva with forceps after topical proxymetacaine $0.5 \%$ (Visonest ${ }^{\circledR}$, Allergan, São Paulo, Brazil) instillation. Filters were pressed for 5 seconds onto the 4 quadrants of the cornea and then the specimens were fixed and stained with polyglandular autoimmune syndrome (PAS), hematoxylin and modified Papanicolau's staining, according to previously described technique ${ }^{(21)}$. Each specimen was analyzed under light microscopy.

IVCM of the cornea was performed using the Heidelberg Retina Tomograph II, Rostock Corneal Module (Heidelberg Engineering, Heidelberg, Germany). A drop of anesthetic (proxymetacaine 0.5\%, Visonest ${ }^{\circledR}$, Allergan, São Paulo, Brazil) was instilled in the eye being examined. The object lens of the microscope was covered with gel (poliacrylic acid $0.2 \%$, Vidisic Ge ${ }^{\circledR}$, Bausch \& Lomb, Berlin, Germany) to contact the cornea. Images were acquired from the central cornea at different depths, from the superficial epithelium to the endothelium. A digital camera placed on the side of the apparatus, giving a lateral image of the patient's eye, controls eye position during examination. We analyzed the following parameters: corneal epithelium characteristics (presence of normal cells, metaplastic cells, conjunctival epithelium cells, goblet cells, inflammatory cells, dendritic cells, neovessels); sub-basal nerve plexus with nerve density; stromal cells and neovessels; and endothelial cells.

Statistical analyses were performed using the Statistical Package for the Social Sciences 13.0 (SPSS Inc., Chicago, IL). Wilcoxon test was used to compare cytology and confocal microscopy.

\section{RESULTS}

Thirteen eyes of 8 patients ( 4 males) were evaluated. Mean age was $48.12 \pm 17.8$ years. The causes of LSCD (and the number or pa- tients and eyes, respectively) were: ocular burn (1 patient, 2 eyes), Staphylococcia $(1,2)$, aniridia $(1,2)$, Stevens Johnson syndrome $(1,1)$, polyglandular autoimmune syndrome $(1,1)$, multiple surgeries $(1,1)$, e idiopathic $(2,4)$.

\section{IMPRESSION CYTOLOGY}

According to inclusion criteria in the study, all cases had goblet cell on cytology samples. Also, all samples showed the presence of conjunctival epithelial cells on the corneal surface, $76.9 \%$ (10 cases ouf of 13) showed squamous metaplasia, and 69.2\% (9/10) showed inflammatory cells in cytological analysis (Figures 1 and 2).

\section{IN VIVO CONFOCAL MICROSCOPY}

IVCM demonstrated that none of the cases had normal corneal epithelial structure (Figures 1 e 2). The basal layer of the corneal epithelium with its cells with bright borders arranged in a regular mosaic
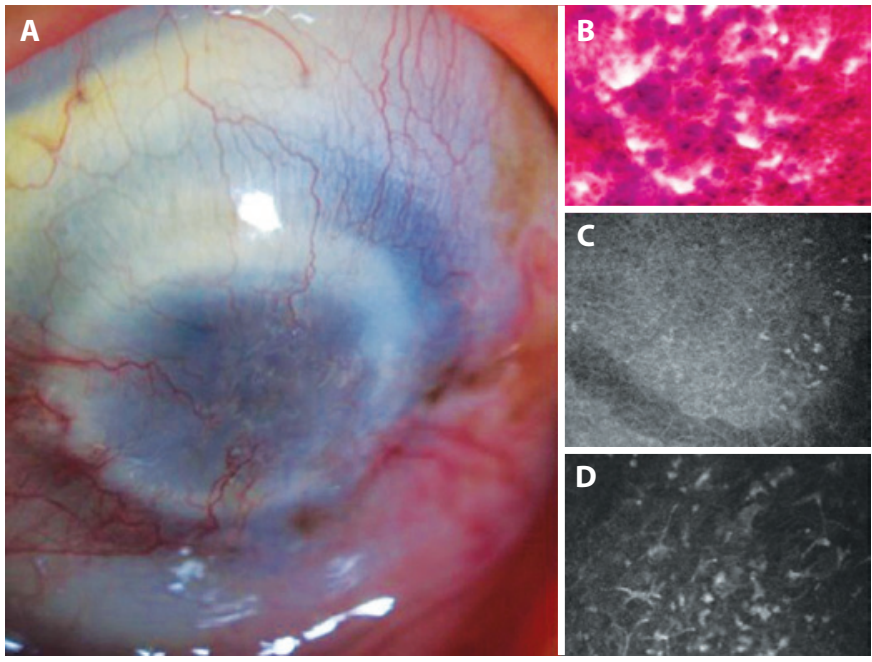

Figure 1. Idiopathic limbal stem cell deficiency, A) biomicroscopy; B) impression cytology with inflammatory cells and conjunctival epithelial cells; $C$ ) in vivo confocal microscopy with corneal and conjunctival epithelia; and D) in vivo confocal microscopy with dendritic cells.
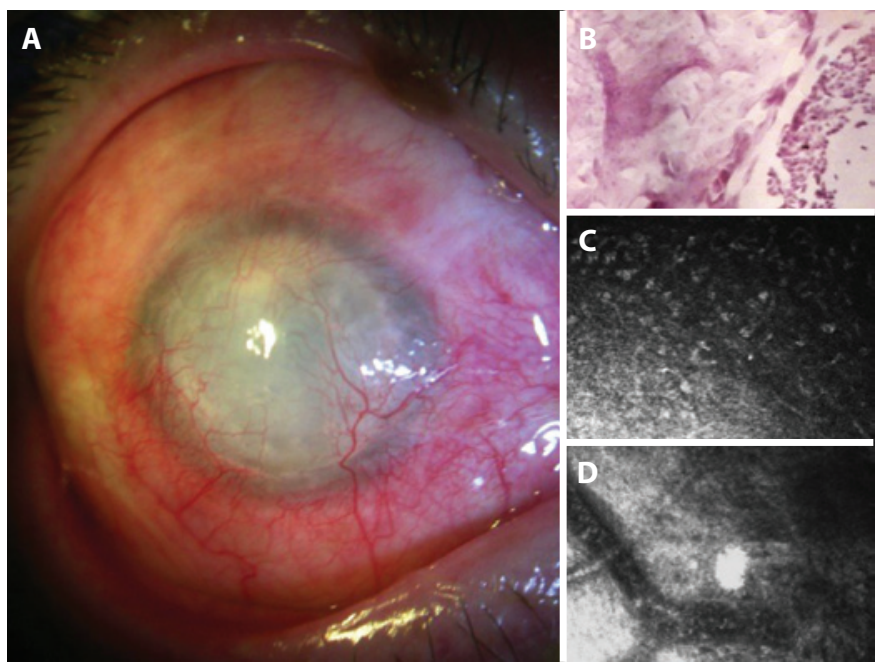

Figure 2. Limbal stem cell deficiency due to multiple surgeries. A) biomicroscopy; B) impression cytology with inflammatory cells, conjunctival epithelial cells bundle, and goblet cells; C) in vivo confocal microscopy with inflammatory and conjunctival epithelium cells; and D) in vivo confocal microscopy with superficial neovessels. 
was seen in $23.1 \%$ ( 3 cases out of 13 ) of the cases by IVCM. No cell could be identified by the IVCM exam, aside from inflammatory cells, at any depth of the cornea in $23.1 \%$ (3/13). Once IVCM depends on light reflection from the tissue being examined, light reflection may become too scattered when cornea opacity is severe. In this situation, the images are rather blurred that no cell can be identified. Although these cases had been diagnosed with LSCD by impression cytology, the images obtained from IVCM were not helpful since no cells could be visualized.

IVCM identified cells suggestive of conjunctival epithelial cells on the cornea in $76.9 \%(10 / 13)$ and goblet cells (typically small, round and hypo-reflective cells) in 69.2\% (9/13). Epithelial squamous metaplasia (seen as larger epithelial cell with diminished nucleus) was present in 15.4\% (2/13). Round hyper-reflective particles suggestive of inflammatory cells were seen in all cases at different epithelial layers. Dendritic hyper-reflective bodies that characterize Langerhans cells were detected in 30.8\% (4/13), all of wich had idiopathic LSCD. The sub-basal nerve plexus was not identified in any of the corneas. Neovessels were seen at the epithelium in $84.6 \%(11 / 13)$ and at the stroma in 53.8\% (7/13). Inflammatory cells at the stroma were seen in $7.7 \%(1 / 13)$. Stromal keratocytes were seen in $7.7 \%(1 / 13)$, in all other cases images were diffusely blurred at the stromal level, probably due to stromal opacity. Endothelial cells were not visualized in any case.

\section{IMPRESSION CYTOLOGY VERSUS IN VIVO CONFOCAL MICROSCOPY}

Cytological and IVCM findings for each patient are presented in table 1. In $76.9 \%$ of the total (10 cases out of 13) the 2 exams agreed on LSCD diagnosis, since both detected conjunctival epithelial cells on the corneal surface. The number of eyes diagnosed as LSCD based on the presence of conjunctival cells on impression cytology or IVCM was not statistically different $(p=0.08)$. There was a difference in the ability of the 2 exams in detecting goblet cells ( $p=0.04$ ), squamous metaplasia $(p<0.01)$, and inflammatory cells $(p=0.04)$. For the 2 former findings, impression cytology showed better performance, and for the latter, IVCM performed better.

\section{DISCUSSION}

A number of alterations were found by corneal IVCM in patients with LSCD. We highlight the finding that corneal layers were not seen in full in most cases. Normal corneal epithelium has superficial, intermediate and basal layers. Since in LSCD this normal composition is not seen and conjunctival epithelial cells are found on the cornea, it is rational to conclude that conjunctival epithelium is replacing corneal epithelium. In some cases, IVCM showed both corneal and conjunctival epithelium at the same image. Nevertheles, even when there was some corneal epithelium on total LSCD, its structure was not normal. IVCM could not detect the sub-basal nerve plexus in our group of patients. Vera et al., examined 15 eyes with LSCD due to Stevens Johnson syndrome and were unable to identify the subbasal nerves on IVCM. It was not clear if the plexus was absent or was just undetectable because of the major modifications associated with the growth of neovessels in the basal section (22).

Impression cytology is the sampling technique of choice for ex vivo evaluation of superficial corneal and conjunctival cells, since it is minimally invasive and can be available for routine clinical use ${ }^{(23)}$. The surface epithelium is the target tissue of interest rather than the basal epithelium or basement membrane. LSCD is confirmed by impression cytology through goblet cells identification on the cornea $a^{(5,8,9)}$ although their absence on the smear may happen by chance and thus does not exclude the diagnosis. Immunohistochemistry may be used on impression cytology specimens to increase the accuracy. While healthy corneas express cytokeratin keratin $12(\mathrm{~K} 12)^{(16)}$, corneas from patients with LSCD are characterized by the presence of mucin 1 (MUC 1) $^{(16)}$ and keratin 19 (K19) ${ }^{(6)}$.

In our study, IVCM findings in corneas with total LSCD were compared to impression cytology findings in order to evaluate IVCM as a tool for LSCD diagnosis. In 10 out of 13 eyes, IVCM was able to detect the presence of cells that were morphologically identical to conjunctival cell over the cornea, thus we found an agreement between the 2 exams on the diagnosis. For the remaining 3 eyes, IVCM could not detect any type of cell due to the haziness of the images (except for inflammatory

Table 1. Impression cytology and in vivo confocal microscopy findings in each patient

\begin{tabular}{|c|c|c|c|c|c|c|c|c|c|}
\hline \multicolumn{10}{|c|}{ Impression cytology and confacal microscopy findings } \\
\hline \multirow{3}{*}{$\begin{array}{l}\text { Patient } \\
\text { (OD/OS) }\end{array}$} & \multirow[b]{3}{*}{ Diagnosis } & \multicolumn{8}{|c|}{ Findings } \\
\hline & & \multicolumn{2}{|c|}{ Goblet cells } & \multicolumn{2}{|c|}{ Conjunctival cells } & \multicolumn{2}{|c|}{ Squamous metaplasia } & \multicolumn{2}{|c|}{ Inflammatory cells } \\
\hline & & IC & IVMC & IC & IVMC & IC & IVMC & IC & IVMC \\
\hline $1(\mathrm{OD})$ & Chemical injury & + & + & + & + & + & & + & + \\
\hline $1(\mathrm{OS})$ & Chemical injury & + & + & + & + & + & & + & + \\
\hline $2(\mathrm{OD})$ & Idiopathic & + & + & + & + & + & & + & + \\
\hline $2(\mathrm{OS})$ & Idiopathic & + & + & + & + & + & & + & + \\
\hline $3(\mathrm{OD})$ & Idiopathic & + & + & + & + & + & & + & + \\
\hline $3(\mathrm{OS})$ & Idiopathic & + & & + & + & & & + & + \\
\hline $4(\mathrm{OD})$ & Staphylococcia & + & + & + & + & + & + & & + \\
\hline $4(\mathrm{OS})$ & Staphylococcia & + & & + & & + & & & + \\
\hline $5(\mathrm{OD})$ & Aniridia & + & & + & & & & & + \\
\hline 5 (OS) & Aniridia & + & & + & & & & & + \\
\hline $6(\mathrm{OS})$ & PAS & + & + & + & + & + & + & + & + \\
\hline $7(\mathrm{OD})$ & SJS & + & + & + & + & + & & + & + \\
\hline $8(\mathrm{OD})$ & Multiple surgeries & + & + & + & + & + & & + & + \\
\hline
\end{tabular}

$\mathrm{OD}=$ right eye; $\mathrm{OS}=$ left eye; $\mathrm{PAS}=$ polyglandular autoimmune syndrome; SJS= Stevens Johnson syndrome; IC= impression cytology; IVCM= in vivo confocal microscopy.

The symbol + indicates the feature's presence. 
cells, that are highly hyper-reflective). Therefore, IVCM did not refute LSCD diagnosis in those cases; it actually was not able to analyze the cells. Light scatter from extremely opaque corneas may limit the quality of the images when corneal opacity is too dense, although moderate or moderate to severe opacity is not a restriction for the exam. Our data showed an agreement between IVCM and impression cytology on LSCD diagnosis in all cases but those 3 in which IVCM images did not show cellularity, supporting that IVCM may be considered a valuable tool for the noninvasive in vivo diagnosis of LSCD.

Some findings were seen on IVCM and not on cytology, including hyper-reflective particles suggestive of inflammatory cells hyperreflective bodies suggestive of dendritic (Langerhans) cells. The latter are deeply situated at the epithelium and basal membrane ${ }^{(24,25)}$ so they are not harvested by the impression sample. If located on central cornea, dendritic cells are indicative of inflammation and are associated with loss of "immune privilege" of the anterior segment, exacerbation of herpetic and other infectious keratitis and amplification of transplant immunity ${ }^{(25)}$. In vivo confocal microscopy thus offer additional information, because impression cytology does not reach deeply located cells, such as inflammatory and Langerhans, that are indicative of corneal inflammation. Also, stromal neovessels and inflammatory cell on the stroma are seen on ICVM but not on impression cytology. All these information are helpful in the clinical context. Conversely, impression cytology as an ex vivo examination allows the use of staining to better evaluate epithelial cell changes ${ }^{(21)}$ and immunohistochemistry techniques to identify corneal and conjunctival cytokeratins ${ }^{(6,16)}$. Therein, IVCM and impression cytology may complement one another. In summary, pros of IVCM are the visualization of deeper tissues, including cells and nerves of all corneal layers, and the possibility of repeated exams over time; at the opposite, as an in vivo exam, it does not allow staining of cells. Another con we found was that IVCM images weren't adequate in cases of severe corneal opacity. Pro of impression cytology is the possibility of cell staining, including immunostaining, and con is that only the surface epithelium is harvested. Impression cytology may also be more available to clinicians than the confocal microscope.

Lanzini et al., studied 15 eyes with suspected corneal conjunctivalization and found that IVCM and immunofluorescence CK12 staining of the cells from impression cytology were concordant on the diagnosis in $87 \%$ of the cases ${ }^{(26)}$. Other study enrolled 58 eyes with ocular chemical injury; IVCM found goblet cells in 9 of them while impression cytology had the same result in 8 eyes. A positive correlation between goblet cell densities in the 2 exams was demonstrated ${ }^{(27)}$. Adequate correlation between the IVCM and impression cytology was also demonstrated in dry eye and rosacea-related epitheliopathy ${ }^{(28)}$. Common findings for both exams in dry eye are squamous metaplasia, inflammatory cell infiltration, goblet cell depletion, as well as a nuclear snake-like chromatin pattern. In rosacea associated with corneal epitheliopathy, goblet cells together with conjunctival epithelial cells within the corneal epithelium layer were found ${ }^{(28)}$.

\section{CONCLUSION}

In our study, frequent IVCM findings in total LSCD were abnormal cells at the corneal epithelium (conjunctival epithelial, goblet and inflammatory cells), corneal neovessels and diffuse hyper-reflection of the stroma. Normal corneal epithelium comprising superficial, intermediate and basal layers was not seen in any case. LSCD had been confirmed by impression cytology in all cases, and $76.9 \%$ of the cases could also be diagnosed by IVCM through the conjunctival epithelial cell visualization on the corneal surface. We also find a limitation of IVCM in total LSCD when corneal opacity is severe. In theses cases, confocal images were rather blurred that no cell can be identified. As a noninvasive technique, IVCM may be considered a valuable tool for LSCD diagnosis, and to follow up the condition and its response to treatment. In our study, patients had total LSCD. Studies with partial LSCD are needed to demonstrate the usefulness of IVCM in less severe cases.

\section{ACKNOWLEDGEMENTS}

We thank Dr. Charles McGhee, MD and Dr. Dipika Patel, MD from the Department of Ophthalmology in Auckland University (New Zealand) for helping us analyze confocal images.

\section{REFERENCES}

1. Dua HS, Joseph A, Shanmuganathan VA, Jones RE. Stem cell differentiation and the effects of deficiency. Eye (Lond). 2003;17(8):877-85.

2. Dua HS, Azuara-Blanco A. Limbal stem cells of the corneal epithelium. Surv Ophthalmol. 2000;44(5):415-25.

3. Tseng SC. Concept and application of limbal stem cells. Eye (Lond). 1989;3(Pt2):141-57.

4. Dua HS, Saini JS, Azuara-Blanco A, Gupta P. Limbal stem cell deficiency: concept, aetiology, clinical presentation, diagnosis and management. Indian J Ophthalmol. 2000; 48(2):83-92. Comment in: Indian J Ophthalmol. 2000:48(2):79-81.

5. Espana EM, Grueterich M, Romano AC, Touhami A, Tseng SC. Idiopathic limbal stem cell deficiency. Ophthalmology. 2002;109(11):2004-10. Comment in: Ophthalmology. 2004;111(1):196; author reply 196

6. Sacchetti M, Lambiase A, Cortes M, Sgrulletta R, Bonini S, Merlo D, et al. Clinical and cytological findings in limbal stem cell deficiency. Graefes Arch Clin Exp Ophthalmol. 2005:243(9):870-6.

7. Hida RY, Mascaro VL, Höfling-Lima AL, Tsubota EG, Gomes JA. Métodos diagnósticos In: Gomes JA, Alves MR, editores. Superfície ocular: córnea, limbo, conjuntiva, filme lacrimal. Rio de Janeiro: Cultura Médica, 2006. p.37-53.

8. Puangsricharern V, Tseng SC. Cytologic evidence of corneal diseases with limbal stem cell deficiency. Ophthalmology. 1995;102(10):1476-85.

9. Calonge M, Diebold Y, Sáez V, Enríquez de Salamanca A, García-Vázquez C, Corrales RM, et al. Impression cytology of the ocular surface: a review. Exp Eye Res. 2004;78(3):457-72.

10. Donisi PM, Rama P, Fasolo A, Ponzin D. Analysis of limbal stem cell deficiency by corneal impression cytology. Cornea. 2003;22(6):533-8.

11. Guthoff RF, Zhivov A, Stachs O. In vivo confocal microscopy, an inner vision of the cornea - a major review. Clin Experiment Ophthalmol. 2009:37(1):100-17.

12. Erie JC, MCLaren JW, Patel SV. Confocal microscopy in ophthalmology. Am J Ophthalmol. 2009:148(5):639-46.

13. Niederer RL, McGhee CN. Clinical in vivo confocal microscopy of the human cornea in health and disease. Prog Retin Eye Res. 2010;29(1):30-58.

14. Tavakoli M, Hossain P, Malik RA. Clinical applications of corneal confocal microscopy. Clin Ophthalmol. 2008;2(2):435-45.

15. Dua HS, Miri A, Alomar T, Yeung AM, Said DG. The role of limbal stem cells in cornea epithelial maintenance: testing the dogma. Ophthalmology. 2009;116(5):856-63.

16. Barbaro V, Ferrari S, Fasolo A, Pedrotti E, Marchini G, Sbabo A, Nettis N, et al. Evaluation of ocular surface disorders: a new diagnostic tool based on impression cytology and confocal laser scanning microscopy. Br J Ophthalmol. 2010;94(7):926-32. Comment in: Br J Ophthalmol. 2010;94(7):956-7; author reply 957-8.

17. Patel DV, McGhee CN. In vivo confocal microscopy of human corneal nerves in health, in ocular and systemic disease, and following corneal surgery: a review. $\mathrm{Br} J$ Ophthalmol. 2009;93(7):853-60. Comment in: Br J Ophthalmol. 2009;93(7):850-2.

18. Rosenberg ME, Tervo TM, Petroll WM, Vesaluoma MH. In vivo confocal microscopy of patients with corneal recurrent erosion syndrome or epithelial basement membrane dystrophy. Ophthalmology. 2000:107(3):565-73.

19. Bozkurt B, Irkec M. In vivo laser confocal microscopic findings in patients with epithelial basement membrane dystrophy. Eur J Ophthalmol. 2009;19(3):348-54

20. Frueh BE, Cadez R, Böhnke M. In vivo confocal microscopy after photorefractive keratectomy in humans. A prospective, long-term study. Arch Ophthalmol. 1998; 116(11):1425-31

21. Barros JN, Mascaro VL, Gomes JA, Freitas D, Hofling-Lima AL. Citologia de impressão da superfície ocular: técnica de exame e coloração. Arq Bras Oftalmol. 2001;64(2):127-31.

22. Vera LS, Gueudry J, Delcampe A, Roujeau JC, Brasseur G, Muraine M. In vivo confocal microscopic evaluation of corneal changes in chronic Stevens-Johnson syndrome and toxic epidermal necrolysis. Cornea. 2009;28(4):401-7.

23. Dart J. Impression cytology of the ocular surface - research tool or routine clinica investigation? Br J Ophthalmol. 1997;81(11):930.

24. Zhivov A, Stave J, Vollmar B, Guthoff R. In vivo confocal microscopic evaluation of Langerhans cell density and distribution in the normal human corneal epithelium. Graefes Arch Clin Exp Ophthalmol. 2005;243(10):1056-61.

25. Mastropasqua L, Nubile M, Lanzini M, Carpineto P, Ciancaglini M, Pannellini T, et al. Epithelial dendritic cell distribution in normal and inflamed human cornea: in vivo confocal microscopy study. Am J Ophthalmol. 2006;42(5):736-44.

26. Lanzini M, Nubile M, Calienno R, Colesanti E, Ciafre M, Curcio C, et al. In vivo confocal microscopy in the diagnosis of corneal conjunctivalization. Acta Ophthalmol. 2008;86(s243):0-0.

27. Le QH, Wang WT, Hong JX, Sun XH, Zheng TY, Zhu WQ, et al. An in vivo confocal microscopy and impression cytology analysis of goblet cells in patients with chemical burns. Invest Ophthalmol Vis Sci. 2010;51(3):1397-400

28. De Nicola R, Labbé A, Amar N, Dupas B, Baudouin C. [In vivo confocal microscopy and ocular surface diseases: anatomical-clinical correlations]. J Fr Ophtalmol. 2005; 28(7):691-8. French 